\title{
IKTIKAD BAIK DALAM KERJA SAMA ANTARA ASOSIASI BONGKAR MUAT DENGAN KOPERASI TENAGA BONGKAR MUAT UPAYA KARYA
}

\author{
R. Juli Moertiono \\ Universitas Pembinaan Masyarakat Indonesia Medan \\ Juli.moertiono88@gmail.com
}

\begin{abstract}
Abstrak
Jenis Penelitian yang digunakan dalam penelitian ini adalah penelitian hukum normatif (normatif research) dengan fokus permasalahan terkait bagaiamana iktikad baik dalam perjanjian kerja sama antara asosiasi bongkar muat dengan koperasi tenaga bongkar muat upaya karya 3) Bagaiamana penyelesaian perselisihan kerja sama antara asosiasi bongkar muat dengan koperasi tenaga bongkar muat upaya karya. Berdasarkan hasil penelitian diketahui bahwa pelaksanaan iktikad baik dalam perjanjian kerja sama antara asosiasi bongkar muat dengan koperasi tenaga bongkar muat upaya karya harus didasarkan pada asas-asas perjanjian diatur dalam KUHPerdata, yang sedikitnya terdapat lima asas yang perlu mendapat perhatian dalam membuat perjanjian: asas kebebasan berkontrak, asas konsensualisme, asas kepastian hukum, asas itikad baik dan asas kepribadian.
\end{abstract}

Kata kunci: itikad baik, kerja sama, asosiasi, bongkar muat, koperasi.

Abstrak

Type of research used in this research is normative research research (normative research) with the focus of related problems is how good is the cooperation agreement between the loading and unloading association with the cooperative of the loading and unloading effort of the work effort. Based on the results of the research note that is implementation of good faith in cooperative agreements between loading and unloading associations with cooperative labor unloading of work effort should be based on principles of agreement set out in the Civil Code, at least five principles that need attention in making the agreement: the principle of freedom of contract, the principle of consensualism, the principle of legal certainty, the principle of good faith and the principle of personality.

Keywords: good faith, cooperation, association, loading and unloading, cooperative.

\section{PENDAHULUAN}

Itikad baik adalah suatu pengertian yang abstrak dan sulit untuk dirumuskan, sehingga orang lebih banyak merumuskannya melalui peristiwaperistiwa dipengadilan. Itikad baik dalam pelaksanaan perjanjian berkaitan dengan masalah kepatutan dan kepantasan. Asas itikad baik dapat dibedakan atas itikad baik yang subyektif dan itikad baik yang obyektif. Itikad baik dalam pengertian yang subyektif dapat diartikan sebagai kejujuran seseorang atas dalam melakukan suatu perbuatan hukum, yaitu apa yang terletak pada sikap batin seseorang pada saat diadakan suatu perbuatan hukum. Sedang itikad baik dalam pengertian yang obyektif dimaksudkan adalah pelaksanaan suatu perjanjian yang harus didasarkan pada norma kepatutan atau apa yang dirasakan patut dalam suatu masyarakat. Itikad baik secara subyektif menunjuk pada sikap batin atau unsur yang ada dalam diri pembuat, sedangkan itikad baik dalam arti obyektif lebih pada hal-hal diluar diri pelaku.

Mengenai pengertian itikad baik secara subyektif dan obyektif, dinyatakan oleh Muhamad Faiz bahwa Itikad baik subyektif, yaitu apakah yang bersangkutan sendiri menyadari bahwa tindakannya 
bertentangan dengan itikad baik, sedangkan itikad baik obyektif adalah kalau pendapat umum menganggap tindakan yang demikian adalah bertentangan dengan itikad baik.

Itikad baik dalam sebuah penjanjian harus ada sejak suatu perjanjian akan disepakati. Dengan kata lain, bahwa itikad baik telah ada pada saat negosiasi prakesepakatan untuk membuat dan/atau menyusun suatu perjanjian. Ridwana Khairandy menyatakan bahwa "Itikad baik sudah harus ada sejak fase prakontrak dimana para pihak mulai melakukan negosiasi hingga mencapai kesepakatan dan fase pelaksanaan kontrak". Itikad baik seharusnya dimiliki oleh setiap individu sebagai bagian dari makhluk sosial yang tidak dapat saling melepaskan diri dari ketergantungan sosial terhadap individu lain untuk saling bekerjasama, saling menghormati dan menciptakan suasana tenteram bersama-sama. Melepaskan diri dari keharusan adanya itikad baik dalam setiap hubungan dengan masyarakat adalah pengingkaran dari kebutuhannya sendiri; kebutuhan akan hidup bersama, saling menghormati dan saling memenuhi kebutuhan pribadi dan sosial.

Keberadaan itikad baik dalam setiap hubungan dengan masyarakat memberi arti penting bagi ketertiban masyarakat, itikad baik sebagai sikap batin untuk tidak melukai hak orang lain menjadi jaminan bagi hubungan masyarakat yang lebih tertib. Ketiadaan itikad baik dalam hubungan masyarakat mengarah pada perbuatan yang secara umum dicela oleh masyarakat, celaan datang dari sikap batin pembuat yang tidak memiliki itikad baik, sikap batin di sini mengarah pada 'kesengajaan sebagai bentuk kesalahan' pembuat yang secara psikologis menyadari perbuatannya serta akibat yang melekat atau mungkin timbul dari pada perbuatan tersebut. Kebebasan berkontrak dan asas pacta sunt servanda dalam kenyataaanya dapat menimbulkan ketidakadilan. Kebebasan berkontrak didasarkan pada asumsi bahwa para pihak dalam kontrak memiliki posisi tawar (bargaining position) yang berimbang, tetapi dalam kenyataaannya para pihak tidak selalu memiliki posisi tawar yang berimbang.

Pada dasarnya perikatan adalah hubungan hukum yang terjadi antara dua orang atau lebih yang terletak dalam lapangan hukum kekayaan, dimana pihak yang satu berhak atas prestasi dan pihak lainnya wajib memenuhinya, dan dalam perikatan terdapat hubungan hukum antara dua orang (2 pihak), berdasarkan kepentingan hak dapat menuntut suatu hal dari pihak yang lain dan pihak yang lain berkewajiban untuk memenuhi kewajiban itu. Secara formil, sebuah perjanjian mengandung beberapa unsur-unsur yaitu; adanya pihak-pihak, adanya persetujuan, adanya tujuan, adanya prestasi, adanya syarat-syarat tertentu, adanya bentuk tertentu.

Suatu perjanjian yang tidak dijalankan dengan itikad baik tentu akan menimbulkan wanperstasi. Mengingat akibat-akibat yang timbul dari wanprestasi itu begitu penting, maka harus ditetapkan terlebih dahulu apakah pihak yang berjanji benar-benar melakukan wanprestasi. Dan apabila hal tersebut disangkal olehnya, maka harus dibuktikan di muka pengadilan. Pada prakteknya memang tidak mudah menyatakan bahwa seseorang itu lalai atau alpa atau melakukan wanprestasi.

Problematika tentang iktiad baik dalam pelaksanaan sebuah perjanjian juga kerap terjadi dalam berbagai bentuk perjanjian termasuk perjanjian kerja sama. Salah satunya dapat dilihat pada Perjanjian Kerja Sama Antara Asosiasi Bongkar Muat Dengan Koperasi Tenaga Bongkar Muat Upaya Karya. Legal standing perjanjian kerja sama dimaksud merujuk pada Instruksi Bersama Menteri Perhubungan dan Menteri Tenaga Kerja Nomor: IM.2/HK.601/PHB-89 dan Nomor: INS.03/MEN/89 tentang Pembentukan Koperasi Pelabuhan Sebagai Pengganti Yayasan Usaha Karya, dan ketentuan 
Peraturan Menteri Perhubungan Nomor: PM.60 Tahun 2014 dan PM. 93 Tahun 2015 tentang Penyelenggaraan Dan Pengusahaan Bongkar Muat Barang.

Adapun perumusan masalah yang akan diteliti lebih lanjut dalam penulisan ini adalah sebagai berikut Bagaimana iktikad baik dalam perjanjian kerja sama antara asosiasi bongkar muat dengan Koperasi Tenaga Bongkar Muat Upaya Karya?. Suatu penelitian ilmiah harus mempunyai tujuan yang jelas dan merupakan pedoman dalam mengadakan penelitian dan juga menunjukkan kualitas dari penelitian tersebut berdasarkan permasalahan yang telah dirumuskan. Maka tujuan yang hendak dikaji dalam penelitian ini adalah Untuk mengkaji pelaksanaan iktikad baik dalam perjanjian kerja sama antara asosiasi bongkar muat dengan Koperasi Tenaga Bongkar Muat Upaya Karya.

\section{METODE}

Penelitian hukum pada dasarnya merupakan suatu kegiatan ilmiah yang didasarkan pada metode, sistematika dan pemikiran tertentu yang bertujuan untuk mempelajari satu atau beberapa gejala hukum tertentu dengan jalan menganalisanya, kecuali itu maka juga diadakan pemeriksaan yang mendalam terhadap fakta hukum tersebut untuk kemudian yang ditimbulkan di dalam gejala yang bersangkutan.

Metode pendekatan yang dilakukan dalam penelitian ini adalah metode pendekatan peraturan perundang-undangan karena pokok permasalahan diarahkan untuk meneliti norma hukum yang ada dalam satu kesatuan (komprehensif), inklusif dalam satu sistem, dan tersusun hirarkis. Pendekatan penelitian ini juga menggunakan pendekatan konsep untuk memahami konsep perjanjian baku dalam hukum perdata dan perlindungan hukum terhadap debitur melalui konsep hukum. Penelitian yang diarahkan untuk mengidentifikasi atau menetapkan konsep tertentu dalam hukum, dilakukan dengan cara memahami, menerima, dan menangkap konsep tersebut untuk dibahas kemudian di dukung dengan data empiris melalui wawancara tidak tertulis pada sumber yang berkompeten terkait dengan judul penelitian yang diangkat untuk diteliti.

\section{HASIL DAN PEMBAHASAN}

3.1 Peraturan Perundang-Undangan dan Sejarah berdiri Asosiasi Bongkar Muat Dengan Koperasi Tenaga Bongkar Muat Upaya Karya

Perusahaan Bongkar Muat merupakan suatu badan usaha yang bergerak di bidang layanan jasa untuk bongkar muat muatan kapal laut. Perusahaan Bongkar Muat (PBM) dikenal diseluruh dunia sebagai Stevedoring Company atau Stevedore saja. Sesuai dengan namanya, PBM melayani jasa bongkar muat muatan kapal laut, namun seiring dengan kebutuhan para pengguna jasa, PBM juga memiliki layanan jasa pemindahan muatan didalam area dermaga atau Cargodoring, layanan penerimaan dan pelepasan barang ke pemilik muatan atau Recieving dan Deliverybahkan ada beberapa PBM yang melayani jasa pemindahan muatan dari dan ke luar area pelabuhan yang disebut juga Overbrengen dalam lingkup usahanya.

Dalam sejarah, usaha bongkar muat belum laama terpisah dari bidang usaha pelabuhan lainnya. Sebelum muncul Instruksi Presiden Nomor 4 Tahun 1985, sistem bongkar muat di pelabuhan seluruh Indonesia dinilai tidak teratur. Maka dengan munculnya Inpres No. 4 Tahun 1985 ditetapkan pemisahan usaha bongkar muat dengan pelayaran dan operator terminal. Hal ini memunculkan banyak peluang bagi pengusaha untuk membuka usaha bongkar muat karena proses bongkar muat muatan kapal laut memang tidak akan berhenti selama kapal masih ada di dunia. Para PBM di Indonesia memiliki asosiasi tersendiri yang berguna untuk menilai PBM dan menjadi wadah aspirasi PBM yaitu Asosiasi Perusahaan Bongkar 
Muat Indonesia (APBMI). Selain itu, usaha bongkar muat dan usaha-usaha kepelabuhanan lainnya di Indonesia di awasi oleh PT. Pelabuhan Indonesia (Pelindo) yang berperan sebagai Badan Otoritas Pelabuhan (BOP).

Namun keadaan ini berubah drastis semenjak muncul Undang-Undang Nomor 17 tahun 2008 tentang pelayaran yang merubah peran Pelindo dari BOP menjadi Badan Usaha Pelabuhan (BUP) yang menghapus peran PBM sebagai pengusaha jasa bongkar muat. Semenjak muncul UU No.17 Tahun 2008 tersebut, berbagai keresahan muncul diantara para pelaku usaha pelabuhan dan Pelindo salah satunya Pelindo dianggap memonopoli usaha bongkar muat dan mematikan usaha PBM - PBM yang berada di Indonesia. Selain itu hubungan antara Pelindo dengan APBMI semakin memburuk dengan ditemukannya PBM yang "palsu" karena hanya bersifat sebagai broker usaha bagi PBM lain. Keresahan tersebut berkurang pada akhir 2010 ketika Pelindo dan APBMI membenahi hubungan mereka denganpembentukan konsorsium PBM di setiap pelabuhan dan terminal dengan rekomendasi dari APBMI sehingga usaha bongkar muat dapat dilakukan bersamasama. Kewenangan dan proporsi kerja tiap konsorsium PBM dengan Operator Terminal (OT) tiap terminal berbeda beda. Terdapat proporsi kerja yang masih dapat menghidupi PBM, namun adapun yang sebaliknya sehingga menyebabkan beberapa PBM gulung tikar.

Berdasarkan Keputusan Menteri Perhubungan No. KM 14 tahun 2002, yang dimaksud dengan Perusahaan Bongkar Muat (PBM) adalah badan hukum Indonesia yang khusus didirikan untuk menyelenggarakan dan mengusahakan kegiatan bongkar muat barang dari dan ke kapal dengan kata lain yaitu penyedia jasa bongkar muat dengan menggunakan Tenaga Kerja Bongkar Muat (TKBM) dan peralatan bongkar muat. PBM di Indonesia berbentuk Perseroan Terbatas, yaitu badan hukum yang didirikan berdasarkan perjanjian, melakukan kegiatan usaha dengan modal dasar yang seluruhnya terbagi dalam saham, dan memenuhi persyaratan dalam undang - undang dan peraturan pelaksanaanya;

\section{Izin Usaha Perusahaan Bongkar Muat}

Agar suatu perusahaan dapat menjalankan usaha bongkar muat sebagai PBM, maka dibutuhkan suatu izin usaha atau izin operasi. Terdapat 2 jenis izin usaha PBM yaitu izin usaha tetap dan izin usaha sementara. Izin usaha tetap berlangsung sesuai dengan waktu berdirinya perusahaan sementara izin usaha sementara diberikan untuk jangka waktu satu tahun saja. Rekomendasi dari APBMI merupakan kewajiban yang harus dimiliki oleh PBM baru, selain itu keseimbangan volume bongkar muat dengan jumlah perusahaan bongkar muat yang ada dan kesempatan perkembangan usaha juga menjadi bahan pertimbangan ketika mengajukan permohonan izin usaha.

Berdasarkan Inpres No. 4 Tahun

1985, dapat diringkas persyaratan pendirian PBM sebagai berikut:

Berbentuk Perseroan Terbatas (PT); (b) Memiliki Akte Usaha dari Notaris; (c) Memiliki modal usaha; (d) Memiliki Nomor Pokok Wajib Pajak (NPWP); (e) Memiliki peralatan bongkar muat sesuai spesialisasi; (f) Memiliki surat keterangan domisili perusahaan;(g) Memiliki tenaga ahli bongkar muat; (h) Memiliki rekomendasi dari Adpel dan Kanpel; (i) Memiliki rekomendasi dari APBMI. Menurut Keputusan Menteri Perhubungan KM 14 tahun 2002, persyaratan pendirian PBM dalam hal aset peralatan bongkar muat PBM adalah PBM yang beroperasi di Pelabuhan Utama wajib memiliki modal dasar sebesar 1 Miliar Rupiah dan disetor sebesar 250 Juta rupiah. Sementara untuk PBM yang beroperasi di Pelabuhan Regional, wajib memiliki modal dasar sebesar 500 Juta Rupiah dan disetor sebesar 125 Juta Rupiah

Layaknya perusahaan profesional, seluruh PBM wajib memiliki Tenaga Ahli 
yang berpengalaman. Berdasarkan Keputusan Menteri KM 14 tahun 2002, bagi PBM yang beroperasi di Pelabuhan Utama, wajib memiliki Tenaga Ahli Nautika Tk. III dengan pengalaman minimal 3 tahun minimal sebanyak 1 orang dan Ahli Ketatalaksanaan Pelayaran Niaga dengan Ijazah minimal D3 dan 3 tahun pengalaman sebanyak minimal 1 orang. Bagi PBM yang beroperasi di Pelabuhan Regional wajib memiliki Tenaga Ahli Nautika Tk. III dengan pengalaman minimal 1 tahun dan sebanyak minimal 1 orang. Begitu juga Ahli Ketatalaksanaaan Pelayaran Niaga dengan Ijazah minimal D3 dan 1 tahun pengalaman sebanyak minimal 1 orang.

\section{Personil Perusahaan Bongkar Muat}

Dalam sebuah organisasi, pekerjaan selalu dilakukan oleh sekelompok orang atau tim. Dalam PBM personil tim tersebut, selain Tenaga Ahli sebagai berikut.

a. Dalam Proses S/D:

1) Stevedore, yaitu pelaksana susunan rencana dan pengendalian kegiatan bongkar muat diatas kapal.

2) Chief Tally Clerk, yaitu penyusun rencana dan pengendali perhitungan fisik, pencatatan dan survey kondisi barang pada setiap pergerakan bongkar muat dan dokumentasi serta penyusun laporan periodik.

3) Foreman, yaitu pelaksana dan pengendali kegiatan operasional bongkar muat barang dari dan ke kapal sampai ke tempat penumpukan barang dan sebaliknya serta membuat laporan periodik hasil kegiatan bongkar muat.

4) Tally Clerk, yaitu pelaksana kegiatan perhitungan, pencatatan jumlah, jenis, merek dan segala kondisi pergerakan barang berdasarkan dokumen serta membuat laporan.

5) Mistry, yaitu pelaksana perbaikan kemasan barang dalam kegiatan S/D.

6) Watchman, yaitu pelaksana keamanan barang pada kegiatan S/D.

Personil-personil di atas tidak semua wajib dimiliki, sebagai contoh posisi Tally sekarang telah diusahakan oleh pihak non PBM salah satunya adalah Jasa Tally Indonesia (JTI) yang beroperasi di Tanjung Perak, Surabaya. Begitu juga dengan posisi Watchman yang dirangkap dengan posisi keamanan pelabuhan. Posisi Mistry pun di Tanjung Perak jarang ditemui karena bagian reparasi kemasan muatan selain Peti Kemas dilakukan oleh TKBM.

Dalam operasional bongkar muat, PBM mengutamakan posisi kerja Operator Crane. Dikarenakan kecepatan bongkar muat menggunakan crane sepenuhnya berada dikendali Operator Crane maka operator memiliki upah yang relatif lebih tinggi dengan adanya insentif per ton muatan yang dikerjakan.

\section{Biaya dan Tarif Bongkar Muat}

a. Biaya Bongkar Muat

Dalam segala proses bisnis selalu terdapat biaya - biaya untuk memproduksi produk perusahaan. Sebagaimana telah diketahui, produk yang dihasilkan oleh PBM adalah jasa bongkar dan muat muatan kapal laut. Untuk menghitung biaya bongkar muat dapat dilakukan dengan memecah proses bisnis mulai dari investasi hingga tiap pergerakan bongkar muat yang dilakukan. Secara umum terdapat beberapa kumpulan biaya yang terdiri dari:

1. Biaya Investasi

2. Biaya Investasi meliputi investasi perusahaan terhadap aktiva-aktiva yang akan digunakan untuk menghasilkan jasa bongkar muat, namun biaya investasi tidak meliputi biaya aktiva apabila aktiva yang digunakan adalah aktiva sewaan. Apabila perusahaan menyewa peralatan maka biaya sewa dikategorikan sebagai biaya operasional.

Biaya Operasional

Biaya operasional meliputi komponenkomponen sebagai berikut: Biaya tenaga per gerakan crane: 
3. Biaya mengangkut peralatan bongkar muat dari tempat penyimpanan ke terminal

4. Biaya Tally

5. Biaya sewa alat

6. Biaya Imbalan jasa untuk operator terminal

7. Biaya Administrasi dan Personil

8. Perlu diketahui, untuk biaya ini dihitung per bulan, bukan per pekerjaan. Namun dari dapat juga dipecahkan perpekerjaan. Adapun biaya reparasi peralatan yang muncul ketika terjadi kerusakan alat.

9. Biaya Reparasi

10. Selain biaya - biaya diatas, terdapat biaya Tally dan Imbalan Jasa. Biaya tally merupakan biaya yang muncul untuk menggunakan jasa Tally.

Namun terdapat dua skenario yaitu PBM menggunakan jasa Tally milik sendiri atau menyewa. Sedangkan biaya Imbalan Jasa merupakan semacam pajak yang dikenakan oleh operator pelabuhan ke PBM sebagai biaya memasukkan aktiva kedalam dermaga. Tariff imbalan jasa adalah Rp. 15,000/Alat/Jam. Dan tariff ini berlaku minimal 8 jam.

b. Tarif bongkar Muat

Dalam penetapan tarif bongkar muat, setiap jenis muatan memiliki kebijakan yang berbeda. Untuk muatan jenis curah, tarif cenderung ditetapkan berdasarkan negosiasi antara pemilik barang atau shipper dengan PBM sendiri. Sehingga sulit untuk menetapkan berapa tarif yang harus dibayarkan, namun tarif dapat diperkirakan dengan memperhitungkan biaya produksi bongkar muat.

Sejak dikeluarkan Intruksi Presiden No. IV / 1985 yang dikeluarkan oleh Presiden kedua Republik ndonesia (Bapak H.M. Soeharto) yang isinya antara lain berbunyi bahwa kepengurusan buruh pelabuhan akan di tata kembali maka Yayasan Usaha Karya (YUKA) yang telah berkembang pesat dan besar menjadi tidak berfungsi kembali atau dibubarkan sesuai dengan Keputusan Bersama Menteri Perhubungan dan Menteri Tenaga Kerja
No. KM.130 / KP.837 / MEN / 86 tentang Pembubaran Yayasan Usaha Karya. Iktikad Baik Dalam Perjanjian Kerja Sama Antara Asosiasi Bongkar Muat Dengan Koperasi Tenaga Bongkar Muat Upaya Karya

Dewasa ini dengan makin kuatnya tuntutan agar perusahaan dalam menyelenggarakan kegiatannya secara bertanggung jawab, yang antara lain berarti mendasarkan kegiatannya pada norma-norma moral dan etika, salah satu tanggung jawab perusahaan adalah meluncurkan produk tertentu sedemikian rupa sehingga kepentingan para konsumen terpelihara.

Dalam rangka pelaksanaan perjanjian, peranan itikad baik (te goeder trouw), sungguh mempunyai arti yang sangat penting sekali. Bahkan oleh Subekti, itikad baik itu dikatakan sebagai suatu sendi yang terpenting dalam hukum perjanjian Hal ini dapat dipahami karena itikad baik merupakan landasan utama untuk dapat melaksanakan suatu perjanjian dengan sebaik-baiknya dan sebagaimana mestinya.

Dalam Pasal 1338 ayat (3) KUH Perdata, mengatur bahwa "suatu perjanjian harus dilaksanakan dengan itikad baik". Asas itikad baik ini sangat mendasar dan penting untuk diperhatikan terutama didalam membuat perjanjian, maksud itikad baik di sini adalah bertindak sebagai pribadi yang baik. Itikad baik dalam pengertian yang sangat subyektif dapat diartikan sebagai kejujuran seseorang, yaitu apa yang terletak pada seseorang pada waktu diadakan perbuatan hukum. Sedangkan itikad baik dalam pengertian obyektif yaitu bahwa pelaksanaan suatu perjanjian itu harus didasarkan pada norma kepatutan atau apa-apa yang dirasa sesuai dengan yang patut dalam masyarakat.

Betapa pentingnya peranan itikad baik dalam pelaksanaan perjanjian, akan sangat kita rasakan terlebihlebih pada masa sekarang, dimana aspek-aspek hidup dan kehidupan masyarakat semakin bertambah banyak dan komplek. Hubungan-hubungan hukum yang berwujud perjanjian- 
perjanjian atau kontrak-kontrak, baik antara anggota masyarakat maupun antara anggota masyarakat dan badan hukum swasta dengan instansi pemerintah, sering tidak begitu sederhana pelaksanaannya.

Bahkan kadangkadang pelaksanaan perjanjian tersebut merupakan suatu rangkaian yang panjang dan memakan waktu yang cukup lama. Tidak heran sementara pelaksanaan suatu perjanjian/kontrak sedang berjalan, tibatiba terjadi perubahan keadaan sedemikian rupa, yang sangat berpengaruh terhadap pelaksanaan perjanjian, yang sebelumnya tidak pernah terbayangkan sehingga tidak ada diatur dalam perjanjian tersebut. Mungkin perubahan keadaan itu mengakibatkan pelaksanaan perjanjian tidak mungkin sesuai seperti diperjanjikan semula. Suatu perjanjian dilaksanakan dengan baik atau tidak, akan tercermin pada perbuatan-perbuatan nyata dari pelaksanaan perjanjian tersebut. Dengan melihat kepada perbuatan-perbuatan nyata pelaksanaan perjanjian itu, maka pelaksanaan perjanjian tersebut dapat diukur secara baik atau tidak. Jadi meskipun itikad baik dalam pelaksanaan perjanjian merupakan sesuatu yang terletak pada hati sanubari manusia yang sifatnya subyektif namun itikad baik itu dapat diukur secara obyektif.

Dari uraian di atas ini dapatlah disimpulkan bahwa itikad baik (te goeder trouw) ketika akan mengadakan hubungan hukum maupun ketika melaksanakan perjanjian, tidak lain daripada sikap mental seseorang manusia yang bersifat subyektif. Berbeda dengan kebanyakan penulis, ahliahli hukum Indonesia yang selalu menganggap itikad baik bersifat subyektif, maka kalangan ahli hukum Belanda antara lain Hofmann dan Vollmar menganggap bahwa di samping adanya pengertian itikad baik yang subyektif juga ada itikad baik yang bersifat obyektif. Ternyata yang dinamakan itikad baik yang bersifat obyektif oleh mereka tidak lain maksudnya adalah kepatutan (billikheid, redelijkheid).
Outwars looking policy yang diterapkan Indonesia sejak lebihurang tahun 1986 telah mendorong cukup signifikan pertumbuhan volume bongkar muat di pelabuhan-pelabuhan Indonesia. Pada tahun 1986 total kegiatan muat barang (loading) untuk kegiatan pelayaran antar pulau dan internasional masingmasing sebesar 45.816.405 ton untuk kegiatan antar pulau dan sebesar 63.588.649 ton untuk internasional. Sedangkan kegiatan bongkar (unloading) sebesar 56.290.479 ton untuk kegiatan perdagangan antar pulau dan sebesar 20.302.445 ton untuk perdagangan internasional. Jumlah ini meningkat terus, sampai pada tahun 2003 jumlah total kegiatan bongkar untuk kegiatan antar pulau sebesar 170.201.242 ton dan kegiatan bongkar untuk kegiatan pengangkutan internasional sebesar 53.776.870 ton. Sementara untuk kegiatan muat sebesar 137.949.398 ton untuk antar pulau dan untuk internasional kegiatan muat mencapai angka sebesar 163.339.487 ton. Peran usaha bongkar muat dalam hal ini sangat strategis, karena bagaimana pun jugakelancaran arus keluar masuknya barang baik untuk kegiatan antar pulaumaupun untuk kegiatan perdagangan internasional akan terganggu jika tidak didukung oleh kegiatan unit usaha bongkar muat. Iklim usaha perdagangan internasional menjadi kurang menarik jika unit usaha bongkar muat mengalami sejumlah kendala.

Ironisnya peran strategis unit usaha bongkar muat tersebut ijalankan justru dalam keadaan kurang mendukungnya piranti hukum yang mengatur usahabongkar muat di Indonesia. Kurang mendukungnya piranti hukum dalam hal inibukanlah dalam pengertian kuantitatif, karena secara faktual banyak sekaliperaturan-peraturan yang mengatur eksistensi unit usaha bongkar muat. Namun secara kualitatif, berbagai peraturan tersebut justru menciptakan keadaan ketidakpastian bagi dunia usaha bongkar muat. Peraturan yang silih 
bergantidengan membawa sejumlah persyaratan dan kondisi yang berubahubahmengaburkan dimensi stability dan predict tability dari unit usaha bongkar muat.

Peraturan Menteri Perhubungan (PM) No. 60 Tahun 2014 tentang Penyelenggaraan dan Pengusahaan Bongkar Muat Barang dari dan ke Pelabuhan. Pertimbangannya lantaran Pasal 3 ayat 4 pada beleid tersebut dinilai kurang sejalan dengan keseluruhan isi PM.Staf Khusus Bidang Keterbukaan Informasi Publik Menteri Perhubungan Hadi M. Djuraid menjelaskan, pasal 3 ayat 4 dalam PM No. 60 Tahun 2014 mengatur secara spesifik tenaga kerja bongkar muat (TKBM) pada perusahaan bongkar muat (PBM) di pelabuhan.

Di antaranya, PBM wajib mempekerjakan TKBM yang berasal dari badan usaha berbentuk badan hukum Indonesia, meliputi perseroan terbatas, koperasi, dan yayasan. "Seharusnya, regulasi hanya mengatur kegiatan pengusahaan bongkar muatnya saja dan tidak mengaitkannya dengan aturan TKBM. Maka dari itu, Pasal 3 ayat 4 akan ditarik dari PM tersebut. Pasal itu pun menimbulkan pro dan kontra di kalangan serikat pekerja bongkar muat dan mereka menuntut untuk dicabut," papar Hadi di Jakarta, saat ini proses pencabutan pasal tersebut tengah menunggu legalitas dari Menteri Perhubungan Ignasius Jonan.

Diharapkan, revisi PM 60 Tahun 2014 rampung tak lama lagi. Selain itu, Kemenhub juga mencabut pasal 16 dalam regulasi tersebut sehingga membatalkan pula PM No 53 Tahun 2015.Semula, lanjut dia, pasal 16 mengatur tentang kewajiban PBM untuk mengasuransikan dan menggunakan TKBM dari koperasi TKBM yang teregistrasi tanpa menyebutkan badan usaha berbentuk perseroan terbatas dan yayasan. Sehingga, aturan PT dan yayasan tersebut dipertegas pada PM 53 Tahun 2015."Dengan adanya penarikan Pasal 3 ayat 4 dan Pasal 16 PM No. 60 Tahun 2014, maka secara otomatis membatalkan secara menyeluruh PM 53 Tahun 2015 yang asalnya revisi pasal 16 PM 60 Tahun 2014," jelas dia.Hadi menyebutkan, revisi PM 60 Tahun 2014 sudah disosialisasikan kepada induk koperasi TKBM di pelabuhan, sejumlah cabang koperasi lainnya, dan beberapa asosiasi pekerja.

Semua entitas tersebut, kata dia, sudah menyetujui adanya penarikan dua pasal pada PM tersebut."Mungkin, bila masih ada protes dari beberapa pihak, kemungkinan itu belum mendapatkan informasi yang update," imbuh dia.Dia mengemukakan, sebetulnya spirit di balik pengaturan badan usaha TKBM pada beleid itu agar ada persaingan yang lebih sehat, sehingga para pekerja pun bisa memiliki nilai tawar yang lebih tinggi.

Saat ini, para TKBM di pelabuhan baru dikoordinasi oleh pihak koperasi di pelabuhan."Justru sebetulnya dengan disahkannya badan hukum lain selain koperasi, sebagai pekerja itu akan menaikkan level kompetensi, sehingga mendongkrak nilai pekerja karena punya pilihan. Mereka bisa punya nilai tawar, apalagi kami juga akan melaksanakan peningkatan kemampuan TKBM pelabuhan melalui pelatihan yang kami biayai dengan anggaran pemerintah," ucap dia.Karena itu, lanjut Hadi, Kemenhub tetap akan membuat regulasi tentang badan usaha TKBM berbadan hukum Indonesia.

Namun, dia menegaskan, saat menyusun aturan itu nantinya, Kemenhub akan berkoordinasi dengan semua pihak, termasuk Kementerian Tenaga Kerja, koperasi pelabuhan, dan asosiasi pekerja."Harapannya itu agar lebih objektif. Tapi spiritnya tetap sama, yakni supaya TKBM di pelabuhan Indonesia memiliki kompetensi yang meningkat serta nilai tawar yang tinggi," tutur dia.Saat ini, pengaturan mengenai pembinaan dan penataan koperasi TKBM diatur dalam Surat Keputusan Bersama Direktur Jenderal Perhubungan Laut, Direktur Jenderal Pembinaan Pengawasan Ketenagakerjaan, dan Deputi Bidang 
Kelembagaan Nomor UU 008/41/2/DJPL11.

Kementerian Perhubungan

(Kemenhub) merevisi Peraturan Menteri Perhubungan (PM) No. 60 Tahun 2014 tentang Penyelenggaraan dan Pengusahaan Bongkar Muat Barang dari dan ke Pelabuhan. Pertimbangannya lantaran Pasal 3 ayat 4 pada beleid tersebut dinilai kurang sejalan dengan keseluruhan isi PM.Staf Khusus Bidang Keterbukaan Informasi Publik Menteri Perhubungan Hadi M. Djuraid menjelaskan, pasal 3 ayat 4 dalam PM No. 60 Tahun 2014 mengatur secara spesifik tenaga kerja bongkar muat (TKBM) pada perusahaan bongkar muat (PBM) di pelabuhan. Di antaranya, PBM wajib mempekerjakan TKBM yang berasal dari badan usaha berbentuk badan hukum Indonesia, meliputi perseroan terbatas, koperasi, dan yayasan."Seharusnya, regulasi hanya mengatur kegiatan pengusahaan bongkar muatnya saja dan tidak mengaitkannya dengan aturan TKBM.

Maka dari itu, Pasal 3 ayat 4 akan ditarik dari PM tersebut. Pasal itu pun menimbulkan pro dan kontra di kalangan serikat pekerja bongkar muat Pasal 16 mengatur tentang kewajiban PBM untuk mengasuransikan dan menggunakan TKBM dari koperasi TKBM yang teregistrasi tanpa menyebutkan badan usaha berbentuk perseroan terbatas dan yayasan. Sehingga, aturan PT dan yayasan tersebut dipertegas pada PM 53 Tahun 2015."Dengan adanya penarikan Pasal 3 ayat 4 dan Pasal 16 PM No. 60 Tahun 2014, maka secara otomatis membatalkan secara menyeluruh PM 53 Tahun 2015 yang asalnya revisi pasal 16 PM 60 Tahun 2014," jelas dia.

Hadi menyebutkan, revisi PM 60 Tahun 2014 sudah disosialisasikan kepada induk koperasi TKBM di pelabuhan. Melaksanakan peningkatan kemampuan TKBM pelabuhan melalui pelatihan yang kami biayai dengan anggaran pemerintah," ucap dia.Karena itu, lanjut Hadi, Kemenhub tetap akan membuat regulasi tentang badan usaha TKBM berbadan hukum Indonesia. Namun, dia menegaskan, saat menyusun aturan itu nantinya, Kemenhub akan berkoordinasi dengan semua pihak, termasuk Kementerian Tenaga Kerja, koperasi pelabuhan, dan asosiasi pekerja."Harapannya itu agar lebih objektif. Tapi spiritnya tetap sama, yakni supaya TKBM di pelabuhan Indonesia memiliki kompetensi yang meningkat serta nilai tawar yang tinggi," tutur dia.Saat ini, pengaturan mengenai pembinaan dan penataan koperasi TKBM diatur dalam Surat Keputusan Bersama Direktur Jenderal Perhubungan Laut, Direktur Jenderal Pembinaan Pengawasan Ketenagakerjaan, dan Deputi Bidang Kelembagaan Nomor UU 008/41/2/DJPL11.

Kemudian Perjanjian Kerja Sama Antara Asosiasi Bongkar Muat Dengan Koperasi Tenaga Bongkar Muat Upaya Karya tidak terlepas dari houm perjanjian.Buku III KUHPerdata Indonesia mengatur tentang perikatan, terdiri dari dua bagian yaitu peraturan-peraturan umum yang berlaku bagi segala macam persetujuan (perjanjian) dari bab I - bab IV dan tentang berbagai perjanjian khusus dari bab V - XVIII.

Jika para pihak dalam suatu perjanjian telah menentukan suatu perjanjian khusus yang mana mengatur tentang peraturan khusus yang mengikat diantara mereka maka peraturan khusus itu dianggap berlaku meskipun dalam peraturan umum telah diatur mengenai hal tersebut. Sehingga berlaku prinsip Lex Specialis derogat legi generale (peraturan perundang-undangan yang khusus mengalahkan peraturan perundangundangan yang bersifat umum, yang mengatur hal sama. Syaratnya mengatur hal yang sama, kedudukannya setingkat, berlaku dalam waktu yang sama, dan saling bertentangan).

Perjanjian tidak bernama, adalah perjanjian-perjanjian yang belum ada pengaturannya secara khusus di dalam 
Undang-Undang, karena tidak diatur dalam KUHPerdata dan Kitab Undang-Undang Hukum Dagang (KUHD). Lahirnya perjanjian ini didalam prakteknya adalah berdasarkan asas kebebasan berkontrak, mengadakan perjanjian atau partij otonomi. Tentang perjanjian tidak bernama diatur dalam Pasal 1319 KUHPerdata, yaitu yang berbunyi: "semua perjanjian, baik yang mempunyai nama khusus maupun yang tidak dikenal dengan suatu nama tertentu, tunduk pada peraturan umum yang termuat dalam bab ini dan bab yang lain”.

Di luar KUHPerdata dikenal pula perjanjian lainnya, seperti kontrak joint venture, kontrak production sharing, leasing, franchise, kontrak karya, beli sewa, kontrak rahim, dan lain sebaginya. Perjanjian jenis ini disebut perjanjian innominaat, yakni perjanjian yang timbul, tumbuh, hidup, dan berkembang dalam praktik kehidupan masyarakat. Keberadaan perjanjian baik nominaat maupun innominaat tidak terlepas dari adanya sistem yang berlaku dalam hukum perjanjian itu sendiri.

Keadaan yang demikian sangat menyulitkan pelaku usaha untuk memahami arah pergerakan pembangunan sektor angkutan laut pada umumnya, khususnya untuk sektor usaha bongkar muat yang ingin dituju oleh pemerintah. Pengakuan hukum atas eksistensi usaha bongkar muat di pelabuhan sebagai bagian integral dari sistem pengelolaan pelabuhan di Indonesia dicantumkan dalam PP No. 2 Tahun 1969 tentang Penyelenggaraan dan Pengusahaan Angkutan Laut.

Berdasarkan PP ini, kegiatan bongkar muat dari dan ke kapal dilaksanakan oleh perusahaan pelayaran melalui unit usaha bongkar muat. Eksistensi dari usaha jasa bongkar muat berdasarkan peraturan ini tidak bersifat sebagai badan usaha yang mandiri, akan tetapi merupakan sub-ordinat dari perusahaan pelayaran dalam waktu yang bersamaan perusahaan Pelayaran melakukan kegiatan angkutan laut baik dengan menggunakan kapal armada maupun dengan menggunakan sistem keagenan. Prospek usaha yang menjanjikan dari usaha bongkar muat menyebabkan terjadinya pembelokan kegiatan usaha perusahaan pelayaran. Kegiatan utama idealnya ditujukan untuk usaha pelayaran (angkutan laut) mengalami pergeseran ke arah usaha bongkar muat. Kecenderungan ini jangka panjang bisa berakibat fatal terhadap sasaran pembinaan usaha pelayaran yang lebih ditujukan sebagai sarana perhubungan untuk membina kesatuan ekonomi negara kepulauan Indonesia serta sebagai instrumen kunci yang menghasilkan efek multiplier bagi pertumbuhan ekonomi nasional.

Pada tahun 1985 pemerintah merubah pola pengembangan usaha jasa bongkar muat ke arah kebijakan yang lebih condong pada pengembangan profesionalitas dan kemandirian usaha jasa bongkar muat. Implementasi Instruksi Presiden Republik Indonesia No. 4 Tahun 1985 tentang Kebijaksanaan Kelancaran Arus Barang Untuk Menunjang Kegiatan Ekonomi telah mengembalikan fungsi pokok usaha pelayaran pada angkutan laut. Dengan model ini, eksistensi perusahaan bongkar muat diakui sebagai usaha mandiri dan bersifat internal.

\section{KESIMPULAN}

Merujuk pada pemaparan hasil penilitian dan pembahasan sebagaimana telah diuraikan di atas, maka dapat ditarik kesimpulan sebagai berikut bahwa Iktikad baik dalam perjanjian kerja sama antara asosiasi bongkar muat dengan koperasi tenaga bongkar muat upaya karya. Itikad baik/good faith dalam kontrak secara jelas yang mandapat menentukan bahwa itikad baik hendaknya diartikan sebagai berikut: Kejujuran dalam membuat kontrak; Pada tahap pembuatan ditekankan, apabila kontrak dibuat di hadapan pejabat, para pihak dianggap beritikad baik (meskipun ada juga pendapat yang menyatakan keberatannya); Sebagai kepatutan dalam 
tahap pelaksanaan, yaitu terkait suatu penilaian baik terhadap perilaku para pihak dalam melaksanakan apa yang telah disepakati dalam kontrak, semata-mata bertujuan untuk mencegah perilaku yang tidak patut dalam pelaksanaan kontrak tersebut.

\section{DAFTAR PUSTAKA}

A.Qirom Syamsudin M. 1985. PokokPokok Hukum Perjanjian Beserta Perkembangannya. Yogyakarta: Liberty. Abdul Kadir Muhammad, 1992. Hukum Perikatan, Bandung: Citra Aditya Bakti. Ahmadi Miru. 2007. Hukum Kontrak Perancangan Kontrak. Jakarta: PT RajaGrafindo Persada.

Agus Yudha Hernoko. 2008. Asas Proporsionalitas Dalam Kontrak Komersial, Yogyakarta: Laksbang Mediatama.

Bryan A. Garner. 2004. Black's Law Dictionary, 8th edition, West St. Paul: Thomson.

Ediwarman. 2015. Monograf Metodologi Penelitian Hukum; Panduan Penulisan Skripsi, Tesis, dan Disertasi., Medan: Sofmedia.

Djaja S. Meliala. 1987. Masalah Itikad Baik dalam KUH Perdata. Cetakan Pertama , Bandung: Bina Cipta.

John Salindheo, 1988. Masalah Tanah Dalam Pembangunan, Cetakan Kedua. Jakarta: Sinar Grafika, 1988.

J.M. Van Dunne dalam Agus Yudha Hernoko, Hukum Perjanjian : Asas Proporsionalitas Dalam Kontrak Komersial, Laksbang Mediatama, Yogyakarta, 2008.

Joni Emirzon. 2000. Alternatif Penyelesaian Sengketa di Luar pengadilan. Jakarta: Gramedia Pustaka Utama.

Kamaluddin. 1983. Sarana Penunjang Angkutan Laut. Jakarta : Bina Aksara.

K. Wantjik. 1997. Hukum Acara Perdata, Jakarta: Ghalia Indonesia.

Khairandy Ridwan. 2003. Itikad Baik dalam Kebebasan Berkontrak. Jakarta:
Pasca Sarjana Fakultas Hukum Universitas Indonesia.

Mariam Darus Badrulzaman. 2001. Kompilasi Hukum Perikatan. Bandung: Citra Aditya Bakti

Mariam Darus Badrulzaman. 2006. KUHPerdata Buku III, Bandung: Penerbit Alumni.

Muhammad Syaifuddin. 2005. Hukum Kontrak Memahami Kontrak dalam Perspektif Filsafat,Teori, Dogmatik, dan Praktik Hukum (Seri Pengayaan Hukum Perikatan). Bandung: Mandar Maju.

M. Solly Lubis. 1994. Filsafat Ilmu dan Penelitian. Bandung: Mandar Maju.

Miles dan Huberman. 1992. Analisis Data Kualitatif: Buku tentang Sumber Data-data Baru. Jakarta: Universitas Indonesia Press. Peter Mahmud Marzuki. 2010. Penelitian Hukum, Jakarta: Kencana Prenada Media Group.

Priyatna Abdurrasyid. 2002. Abitrase dan Alternatif Penyelesaian Sengketa. Jakarta: Fikahati Aneska.

P.N.H., Simanjuntak. 2009. Pokok Pokok Hukum Perdata Indonesia, Jakarta: Djambatan.

Retno Prabandari. 2007. Jenis-jenis Perjanjian Sebagai Dasar Hukum Dalam Pengalihan Hak Guna Bangunan Objek Hak Tanggungan. Tesis. Semarang: Universitas Diponegoro.

Reinhard Zimmerman and Simon Whitttaker. 2000. Good Faith in European Contract Law. USA: Cambridge University Press.

Riduan Syahrani. 1992. Seluk Beluk dan Asas-Asas Hukum Perdata. Bandung: Alumni.

R. Subekti. 2011. Pokok-Pokok Hukum Perdata. Jakarta: PT. Intermasa.

S.B March dan J. Soulsby alih Bahasa oleh Abdulkadir Muhammad. 2006. Hukum Perjanjian, Bandung: Alumni.

Sentosa Sembiring. 2006. Himpunan Lengkap Peraturan Perundang-Undangan tentang Badan Peradilan dan Penegakan Hukum, Bandung: Nuasa Aulia. 
Sudikno Mertokusumo. 1986. Rangkuman

Kuliah Hukum Perdata, Yogyakarta: Fakultas Pascasarjana UGM.

------. 2004. Penemuan Hukum.

Yogyakarta: Liberty, halaman 9.

Sudaryo Soimin. 1994. Status Tanah Dan

Pembebasan Tanah. Jakarta: Sinar

Grafika.

Sumadi Suryabrata. 2006. Metodologi Penelitian. Jakarta: Rajawali Pers.

Soerjono Soekanto. 1981. Pengantar Penelitian Hukum, Jakarta: UI Press.

---------. 1982. Kesadaran Hukum dan

Kepatuhan Hukum, Jakarta: Rajawali.

Titik Triwulan Tutik. 2008. Hukum Perdata dalam sistem Hukum Nasional, Jakarta: Penerbit Prenada Media Group.

Uyono, C. R. 2007. Shipping: Pengangkutan Intermodal Ekspor Impor Melalui Laut. Jakarta: Percetakan Argya Putra.

Wirjono Projhodikoro. 1982. Hukum Perkapalan dan Pengangkutan Laut. Jakarta: Bina Aksara, halaman 10.

-----. 2006. Asas-Asas Hukum

Perjanjian. Bandung: Bandung.

Kitab Undang-Undang Hukum Perdata

Kitab Undang-Undang Hukum Dagang.

Undang-Undang No 21 Tahun 1992

tentang Pelayaran.

Peraturan Pemerintah No.61 Tahun 1954 tentang Penetapan Peraturan Mengenai Perusahaan Muatan Kapal Laut.

Peraturan Pemerintah No.5 tahun 1964 tentang Penyelenggaraan dan Pengusahaan Angkutan Laut Peraturan Pemerintah No.2 Tahun 1969 tentang Penyelenggaraan dan Pengusahaan Angkutan Laut.

Peraturan Pemerintah No. 82 Tahun 1999 tentang Angkutan di Perairan Peraturan Pemerintah RI No.69 Tahun 2001 tentang Kepelabuhanan

Keputusan Bersama Direktur Jenderal Perhubungan Laut, Direktur Jenderal Pembinaan Hubungan Industrial dan Pengawasan Ketenagakerjaan dan Deputi Bidang Kelembagaan Koperasi dan Usaha Kecil dan Menengah Nomor :AL.59/1/1202 ; 300/BW/2002; 113/SKB/DEP. I/VIII/2002 tentang Pembinaan dan
Pengembangan Koperasi Tenaga Kerja Bongkar Muat (TKBM) Di Pelabuhan.

Keputusan Menteri Perhubungan No: KM 13 Tahun 1989 Tentang Pembinaan Perusahaan Bongkar Muat.

Keputusan Menteri Perhubungan No: KM 14 Tahun Tahun 2002 Tentang Tata Cara Bongkar Muat Barang.

Keputusan Menteri Perhubungan No: KM 25 Tahun 2002 Tentang Pedoman Dasar Perhitungan Tarif Pelayanan Jasa Bongkar Muat dari dan ke Kapal di Pelabuhan.

Anonim. "Teori Keadilan Menurut Aristoteles, Plato, Thomas Hobbes". Dalam

http://pusatinformasi212.blogspot.co.id/20 17/04/teori-keadilan-menurut-aristotelesplato-thomas-hobbes.html, diakses pada hari Kamis, 01 Februari 2018, Pukul $20.15^{\mathrm{WIB}}$.

Bambang Sutiyoso. 2013. "Penafsiran Kontrak Menurut Kitab Undang-Undang Hukum Perdata dan Maknanya Bagi Para Pihak yang Bersangkutan," Jurnal Hukum Ius Quia Iustum, Vol. 20, No. 2, halaman 222.

Faiz. "Muhammad. Kemungkinan diajukan Perkara dengan Klausula Arbitrase ke Muka Pengadilan". Dalam www.panmuhamadfaiz.co. diakses hari Senin, tanggal 12 September 2006, Pukul $12.00^{\mathrm{Wib}}$

http://www.legalakses.com/asas-asas-

perjanjian/. diakses 12 Juni 2017, pukul $12.30^{\mathrm{WIB}}$.

https://id.wikipedia.org/wiki/Kerja_sama, diakses pada hari Kamis, 01 Februari 2018, pukul $21.36^{\mathrm{WIB}}$.

http://suaratkbm.com/regulasi/sejarah-

koperasi-tkbm-pelabuhan di akses tertanggal 12 September 2017, Pukul $07.30^{\mathrm{WIB}}$

http://www.dephub.go.id/berita/baca/atura n-kemenhub-tentang-bongkar-muatbarangdirevisi/?cat=U29zaWFsaXNhc2kgUGVy YXR1cmFufHNlY3Rpb24tNi di akses tertanggal 23 Juni 2017, pukul 17.30 WIB

M. Edy Sentosa, "Metode Metode Penelitian", dalam 
hhtp//theglobalgenerations.blogspot.com, diakses pada tanggal 21 Agustus 2014, pukul $21.30^{\mathrm{WIB}}$.

"Perjanjian Bernama dan Perjanjian Tidak Bernama",

http://iyudkidd02street17.blogspot.com, diakses pada tanggal 02 September 2014, pukul $20.21^{\text {WIB }}$

, diakses tanggal 11 Juni 2015, pukul 17.30 ${ }^{\mathrm{WIB}}$.
Siti Ismijati Jenie, 2007, "Itikad Baik Perkembangan dari Asas Hukum Khusus Menjadi Asas Hukum Umum di Indonesia", Pidato Pengukuhan Jabatan Guru Besar, FakultasHukum Universitas Gajah Mada Yogyakarta, www.ugm.ac.id/index.php?page=rilis\&arti $\underline{\mathrm{kel}}=927$ 